\title{
Richeza (c. 996-1063) - la reina consorte de Polonia - sabia o instigadora?
}

Anna Działak

\section{OpenEdition}

\section{Journals}

\section{Edición electrónica}

URL: http://journals.openedition.org/medievalista/422

DOI: $10.4000 /$ medievalista.422

ISSN: 1646-740X

\section{Editor}

Instituto de Estudos Medievais - FCSH-UNL

\section{Referencia electrónica}

Anna Działak, « Richeza (c. 996-1063) - la reina consorte de Polonia - sabia o instigadora? », Medievalista [En línea], 14 | 2013, Puesto en línea el 01 julio 2013, consultado el 02 mayo 2019. URL : http://journals.openedition.org/medievalista/422 ; DOI : 10.4000/medievalista.422

\section{(C) IEM}


Título: Richeza (c. 996-1063) - la reina consorte de Polonia - sabia o instigadora? Autor(es): Anna Dzialak

Enquadramento Institucional: Instituto de Estudos Ibero e Ibero-Americanos, Universidade de Varsóvia, Varsóvia, Polónia

Contacto: anna.dzialak@ hotmail.com

Fonte: Medievalista [Em linha]. №14, (Julho - Dezembro 2013). Dir. José Mattoso.

Lisboa: IEM.

Disponível em: http://www2.fcsh.unl.pt/iem/medievalista/

ISSN: $1646-740 \mathrm{X}$

\section{Resumo}

Richeza (c. 996 - 1063) era mujer de Miecislao II Lampert - segundo rey de Polonia y nieta de Otón II - emperador del Sacro Imperio Romano. Esta mujer sabia, activa tanto en el campo político como en el religioso parece, sin embargo, no encontrar el debido reconocimiento en las cronícas medievales polacas. Además, la imagen historiográfica de esta mujer excepcional, crecida en uno de los ambientes más ilustres de aquel entonces, se vio deformada tanto en las cronícas medievales como en la tradición posterior. El objetivo del presente estudio consiste en analizar dichas deformaciones y mostrar sus posibles causas. Se pretende comparar la figura de Richeza con las de otras mujeres poderosas y excepcionales del ámbito de la cultura del Medioevo europeo para estabelecer subyacentes patrones culturales.

Palavras-chave: Richeza, história da Polónia medieval, história das mulheres, crónicas medievais polacas, padrões culturais. 


\section{Abstract}

Richeza (b. ca. 996 - d. 1063) was the wife of Mieszko II Lambert - the second King of Poland and the granddaughter of Otto II - the Holy Roman Emperor. That educated woman, active both in the political arena and the arena of faith, did not enjoy, however, a merited acclaim in the chronicling of Middle Ages. What is more, the historiographic portrayal of that exceptional woman emerges as highly disfigured in the chronicles of medieval Poland and in the literature that followed. The objective of the current examination is to delve into analyzing that disfigurement and to depict its potential cause. It is also intended to juxtapose the figure of Richeza to other prodigious and prominent female figures representative of the circle of European culture. This is all in order to reconstruct the concealed cultural patterns.

Keywords: Richeza, medieval history of Poland, women's history, Polish medieval chronicles, cultural patterns. 


\title{
Richeza (c. 996-1063) - la reina consorte de Polonia - sabia o instigadora? ${ }^{1}$
}

\author{
Anna Działak
}

\section{A manera de introducción}

\begin{abstract}
Aunque los caballeros se quejaban por diferentes tributos, cargas e impuestos que había inventado e impuesto la reina Richeza lo que más les disgustaba, era que la reina con sus mañas e influencias no dejaba que se suprimiesen estas cargas tributarias, a pesar de varias súplicas presentadas ante ella y ante su hijo Casimiro. Lo más amargo en todo eso era que [...] la propia reina Richeza desde hacía mucho tiempo tanto en vida de su marido rey Miecislao, como después de su muerte odiaba a los polacos, le disgustaban sus costumbres y su idioma y, a menudo, les injuriaba. Además, tenía en su comitiva y en altos puestos a alemanes y, a decir verdad, despreciaba a los señores polacos y a sus hijos - aunque eran de noble estirpe - preferiendo a los alemanes. ${ }^{2}$
\end{abstract}

Altos tributos e impuestos, odio a su pueblo, preferencia por los extranjeros - así retrató a Richeza Jan Długosz (1415 - 1480) - el más destacado cronista medieval polaco. Hay apenas una inexactitud - la reina tan cruelmente descrita es una de las que más han sobresalido en la historia de Polonia y de las que con más éxito han apoyado el desarrollo cultural del país. ¿Cómo y por qué llegó esta mujer sabedora y notable a ser

\footnotetext{
${ }^{1}$ La primera versión del siguiente artículo se aceptó para ser presentada durante el XVI Coloquio de la AEIHM "Comiendo del Fruto Prohibido: Mujeres, Ciencia y Creación a través de la Historia" (Salamanca, 4 - 5 octubre 2012). Sin embargo, debido a un repentino compromiso, la autora no pudo comparecer al Coloquio.

2 Joannis Dlugossii Annales seu Cronicae Incliti Regni Poloniae. ed. crítica Jan Dąbrowski et al. Warszawa: PWN, 2009. Libro II, p. 390. Traducción nuestra.
} 
tan injustamente criticada, pasados cerca de 300 años desde su muerte? ¿Por qué sus méritos no encontraron el reconocimiento debido? En el presente estudio intentaremos responder a estas preguntas, redimiendo la imagen de la reina y desmontando una de las más oscuras mi(s)tificaciones de la historiografía medieval polaca. Para tal efecto yuxtapondremos la escasa base cronística medieval junto con opiniones de historiadores modernos, y presentaremos las acciones fundacionales de la reina.

\section{Fondo histórico}

Richeza (? - 1063) era hija de Matilde (980 - 1025), hija de Otón II (955 - 983) y de Teófano (956 - 991), y de Ezzo Ehrenfried (955 - 1034) - palatino de Lotaringia. Las nupcias de sus padres - celebrados entre nieta, hija y hermana de emperadores y un aristócrata provinciano - probablemente causaron gran escándalo. Thietmar, el cronista alemán más importante de esa época y el único que menciona el hecho en vida de Ezzo y Matilde, no le consagra mucho espacio a ese evento, contentándose con un comentario lacónico. ${ }^{3}$ Dice el cronista: «Cesaris eiusdem soror Mathild nomine Herimanni comitis palatini filio Ezoni nupsit. Et hoc multis displicuit. Sed quia id non valuit emendare legaliter, sustulit hoc unicus frater illius pacienter, dans ei quam plurima, ne vilescerte innata sibi a parentibus suumis gloria.» ${ }^{4}$

Fundatio monasterii brunwilarensis, la fuente posterior, aunque más próxima al matrimonio, ya que fue creada en su fundación, presenta la versión más detallada y más sorprendente. De acuerdo con la crónica, Ezzo logró la mano de la princesa al ganar un partido de dados o de ajedrez con el emperador ${ }^{5}$ Como destaca Michał Tomaszek, es de suponer que, con esa historia pintoresca, el cronista intentara justificar el matrimonio celebrado entre dos personas de condición desigual. Al mismo tiempo, puesto que la historia apareció en los círculos cercanos al palatino, pudo servir para realzar la

\footnotetext{
${ }^{3}$ TOMASZEK, Michał - Klasztor i jego dobroczyńcy. Średniowieczna narracja o opactwie Brauweiler i rodzinie królowej Rychezy. Kraków: Avalon, 2007, p. 126.

${ }^{4}$ Kronika Thietmara. trad., introd., y notas Marian Zygmunt Jedlicki. Poznań: Instytut Zachodni, 1953. Libro IV, p. 229.

${ }^{5}$ Como destaca Michał Tomaszek, la expresión tabula alearum, usada por el cronista, puede referirse a diferentes juegos de tablero conocidos en esa época. TOMASZEK, Michał - Klasztor i jego... op.cit., p. 129.
} 
importancia de su familia. ${ }^{6}$ Probablemente nunca sabremos qué juegos políticos dieron como resultado ese matrimonio: las fuentes son parciales (incluido Fundatio monasterii brunwilarensis que, como demostró Michał Tomaszek, en varias ocasiones es de poca fiabilidad $^{7}$ ) y, sobre todo, escasas.

De acuerdo con las fuentes históricas Matilde tuvo con Ezzo una prole numerosa: tres hijos y siete hijas, entre ellas Richeza - la que nos interesa en el presente estudio. Como todas las mujeres de buena estirpe, Richeza recibió una buena formación conventual. La futura reina de Polonia probablemente creció en Gandersheim o en Quedlinburg, donde sus tías desempeñaban altas funciones conventuales. ${ }^{8}$ No hay que olvidar que, en esa época, los conventos femeninos constituían una "válvula de escape" para la creatividad de las mujeres. Fue precisamente en esa época y en ese ambiente, en el que Hroswita creaba sus obras de teatro. ${ }^{9}$ Además, tras ataques normandos, que forzaron a los monjes irlandeses a abandonar sus conventos, Alemania, y concretamente Lotaringia, se vieron transformados en el corazón del occidente cristiano. ${ }^{10}$ Cabe destacar que la situación de mujer en Alemania era bastante privilegiada, sobre todo en el caso de las monjas que disfrutaban de varios privilegios y libertades. ${ }^{11}$ Por lo tanto, es de suponer que Richeza recibió una instrucción muy buena y que poseía todos los méritos inherentes a las altas funciones, ya que fuesen eclesiásticas o reales.

Descendente de reyes y emperadores, heredera de la tradición latina y bizantina, ${ }^{12}$ bien educada y formada, sabedora de varios idiomas, Richeza, en 1013, contrajo matrimonio con Miecislao Lampert (990 - 1034) - príncipe polaco de la dinastía de los Piastas probablemente desde joven destinado a ser heredero de su padre. Prole de un matrimonio contraído entre dos personas de condición desigual, ella también se vio casada con un príncipe de un país recién-cristianizado y, por muchos, visto todavía

\footnotetext{
${ }^{6}$ Ibidem, 130.

${ }^{7}$ Ibidem, pp. 224-253.

${ }^{8}$ ŻYLIŃSKA, Jadwiga - Piastówny i żony Piastów. Warszawa: PIW, 1967, 51.

9 A propósito de otras monjas ilustres veáse por ejemplo: RADZIMIŃSKI, Andrzej - Kobieta w średniowiecznej Europie. Toruń: Wydawnictwa Naukowe UMK, 2012.

${ }^{10}$ ŻYLIŃSKA, Jadwiga - Piastówny... op.cit., pp. 51-52.

${ }^{11}$ Durante todo el Medievo las abadesas disfrutaban de plena jurisdicción en sus territorios conventuales. Además, las monjas gozaban de muchas libertades, entre otras podían viajar y tenían derechos personales. ŻYLIŃSKA - Jadwiga, Piastówny... op.cit., pp. 52-53).

12 Richeza era nieta de la princesa bizantina Teófano, una de las mujeres más influyentes del Sacro Imperio Romano.
} 
como un país bárbaro. Como en el caso de matrimonio de sus padres, también esa unión debió causar un gran escándalo. Thietmar, que en otras ocasiones menciona todas las filiaciones de casas nobles alemanas - sea de una manera tan lacónica como en el caso los padres de Richeza, sea de una manera más detallada - ni siquiera menciona ese matrimonio. ${ }^{13}$ Es de suponer, no obstante, que su recato es una herramienta retórica y constituye un comentario per se, puesto que Thietmar, en varias ocasiones, se dio a conocer como un gran enemigo del padre de Miecislao - Boleslao (967 - 1025). Así, el silencio desprendido por el obispo, probablemente demuestra el descontento de las clases altas, provocado por las nupcias celebradas entre el príncipe "bárbaro" y la nieta y sobrina de emperadores, respectivamente Otón II y Otón III. ${ }^{14}$

No obstante, aunque proveniente de un país recién-cristianizado, Miecislao Lampert era un buen partido para Richeza: bien formado y educado, sabía hablar varios idiomas ${ }^{15}$ y hay quien afirma que había sido destinado por Otón III para heredar el trono del Sacro Imperio Romano - hecho imposibilitado por la repentina muerte del emperador. ${ }^{16} \mathrm{El}$ matrimonio contraído entre personas ilustres, de una edad semejante probablemente estaba bien visto en Polonia y en algunos círculos del Sacro Imperio. ${ }^{17}$

Tres años después de la boda Richeza, dio a luz a su primer hijo: Casimiro (1016-1058) - hijo primogénito y futuro heredero de su padre. Después nacieron Gertrudis y una hija cuyo nombre desconocemos ${ }^{18}$ - a quienes el curso de la historia también guardaba un papel importante. La descendencia de Richeza y Miecislao, tal y como sus padres, recibió muy buena instrucción. Su trayectoria vital demuestra, claramente, que Richeza les transmitó todos sus valores resultantes de la tradición doble - latina y bizantina - en la que había crecido.

\footnotetext{
${ }^{13}$ Como subraya Kazimierz Jasiński igualmente menciona matrimonios contraidos por las hermanas de Miecislao, o sea estaba a par de la situación en Polonia. JASIŃSKI, Kazimierz - Rodowód pierwszych Piastów. Poznań: WPTPN, 2004, p. 115.

${ }^{14}$ TOMASZEK, Michał - Klasztor i jego... op.cit., p. 157.

15 De acuerdo con la carta escrita por Matilde, hija del príncipe Hermann, además de alemán y polaco sabía hablar y leer griego y latín. Se dió a conocer como un buen diplomático y una persona docta en liturgía. La carta prueba también que, sin duda, era letrado. SCZUR, Stanisław y OŻÓG, Krzysztof (coords.) - Piastowie. Leksykon biograficzny. Kraków: Wydawnictwo Literackie, 1999, p. 41.

${ }^{16}$ ŻYLIŃSKA, Jadwiga - Piastówny... op.cit., p. 51.

${ }^{17}$ A la hora de casarse con Richeza, el príncipe rondaba los 23 y la novia, probablemente, los 20 años.

18 Algunas fuentes sugieren que se llamaba Richeza, tal como su madre. Sin embargo, los últimos estudios rechazan esa posiblidad. TRAWKOWSKI, Stanisław - "Rycheza". In KIENIEWICZ, Stefan (coord.) - Polski Słownik Biograficzny. Kraków: IH PAN, 1991-1992. Vol. XXXIII, p. 372.
} 
Cuando en 1025 murió Boleslao - el padre de Miecislao - el hijo predilecto (que no el mayor) subió al trono con el título real. Richeza se dio a conocer como una digna compañera del rey: ayudaba a su marido en el ejercicio del poder real y en las actividades culturales, desempeñadas, sobre todo, a través de las fundaciones eclesiásticas y los amplios contactos con Lotaringia y Renania. Apenas duró seis años la felicidad de la pareja real. En 1031 el matrimonio se separó, supuestamente, a causa de una infidelidad conyugal del rey. Se supone que Richeza no pudo aceptar el ultraje y emigró a Sajonia, llevándose consigo a sus hijos. Sin embargo, su viaje forzoso no sólo era a causa de la supuesta indignación, o por las intrigas de la(s) supuesta(s) concubina(s) ${ }^{19}$ de Miecislao, sino también debido al motín provocado contra el rey por sus hermanos. Como subraya Gerard Labuda no se pueden aceptar las intrigas como la única causa de la separación. ${ }^{20}$

Ya hemos mencionado que Miecislao, aunque era el hijo predilecto de Boleslao, no era su hijo primogénito. En el fatídico año 1030 Bezprym $^{21}$ y Otón ${ }^{22}$ - sus hermanos - con la ayuda de Sacro Imperio Romano y de la Rus' atacaron Polonia, desterrando a Miecislao. A ésta se le sumaron otras tragedias personales: la mencionada separación, la probable castración del $\operatorname{rey}^{23}$ y la devastación del reino. En 1032 Miecislao llegó

${ }^{19}$ Diferentes fuentes no están de acuerdo en lo que se refiere al suceso. La crónica de Brauweiler afirma que la separación fue a causa de una mujer concreta, cuyo nombre desconocemos (Mnich Brunwilerski o założeniu klasztoru $w$ Brunwiler. In BIELAWSKI, August - Monumenta Poloniae Historica. Volume 1. Warszawa: PWN, 1960, p. 346). Jan Długosz afirma que Miecislao tuvo varias relaciones extraconyugales y que su comportamiento disoluto probablemente fue uno de los porqués de su muerte (Joannis Dlugossii Annales... op.cit., p. 384-387.). Ambos los textos llaman a la(s) antagonista(s) de la reina pellex. Ni Gallus Anonimus ni Wincenty Kadłubek mencionan el hecho. Como destaca Gerard Labuda la historia debe ser interpretada como un típico rumor palaciego, sin embargo no hay fundamentos para ponerlo en duda (LABUDA, Gerard - "Uwiezienie polskich insygniów koronacyjnych do Niemiec w 1031 r.". In Gawinowa Danuta et al - Kultura średniowieczna $i$ staropolska: studia ofiarowane Aleksandrowi Gieysztorowi w pięćdziesięciolecie pracy naukowej, Warszawa: PWN, 1991, p. 224.).

${ }^{20}$ Ibidem.

${ }^{21}$ Hijo de una princesa húngara, de nombre desconocido y, de acuerdo con relatos cronístios, no muy querida por Boleslao. Sin embargo, era hijo primogénito de Boleslao. El padre le alejó del poder, destinándole a la vida monástica, con lo que Bezprym nunca se conformó.

${ }^{22}$ Hermano menor de Miecislao, de la misma madre que él - la tercera y la esposa predilecta de Boleslao - Emnilda.

${ }^{23}$ No todas las fuentes confirman ese suceso. La historia transmitida por Gallus Anonimus (Kronika Polska Anonima tzw. Galla. Trad. Roman Grodecki, introd. y notas Marian Plezia. Wrocław: Ossolineum, 1975. Libro I, p. 43), el primer cronista polaco, se ve silenciada en las crónicas posteriores, a saber las crónicas de Wincenty Kadłubek y de Jan Długosz. Como afirma Aleksander Gieysztor la historia de la castración se integra en la tradición de la corte polaca (Mieszko II Lambert. In KIENIEWICZ, Stefan (coord.) - Polski Słownik Biograficzny. Kraków: IH PAN, 1976. Vol. XXI, p. 34.). Sea como fuere, no se

Medievalista online $\mathrm{N}^{0} 14 \mid$ Julho - Dezembro 2013 @ IEM - Instituto de Estudos Medievais 7 
a recuperar su herencia, aunque simplemente con un título ducal y en un territorio reducido. ${ }^{24}$ En 1034, el marido de Richeza murió con apenas 44 años hay quien afirma que se trató de un fallecimiento inesperado ${ }^{25}$. Después de la repentina muerte de Miecislao subió al poder su hijo Casimiro. Richeza probablemente ya no volvió a Polonia - permaneció en Alemania hasta su muerte en $1063 .{ }^{26}$ Durante su estancia en su tierra natal confirmó su condición docta, a través de actividades de mecenazgo, fundaciones y apoyo tanto moral, como material prestado a sus hijos.

\section{Richeza - continuadora de las tradiciones familiares. Fundaciones y política}

Como ya hemos mencionado, Richeza creció en uno de los más ilustres ambientes de esa época. La reina pertenecía a una familia de mujeres fuertes y sobresalientes. Su abuela - Teófano - princesa bizantina y mujer de Otón II, desempeñaba en la corte imperial varias funciones importantes. Merecía también buena opinión de Thietmar, quien escribió sobre ella: «Haec, quamvis sexu fragilis, modestae tamen fiduce et, quod in Grecia rarum est, egregiae conversationis fuit regnumque filii eius custodia servabat virili, demulcens in omnibus pios terrensque ac superans erectos.» ${ }^{27}$ Además, en otras ocasiones, el cronista alemán alabó su postura cristiana y virtudes morales. ${ }^{28}$ Matilde -

sabe de otra prole nacida de Miecislao después de su estancia en Bohemia, donde, de acuerdo con Gallus Anonimus, le castró Ulrico.

${ }^{24}$ Aunque oficialmente renunció al título real, siguió siendo llamado rey. ŻYLIŃSKA, Jadwiga Piastówny... op.cit., p.58. También Richeza guardó el título. SCZUR, Stanisław y OŻÓG, Krzysztof (coords.) - Piastowie..., op.cit., p. 46.; JASIŃSKI, Kazimierz - Rodowód... op.cit., p. 116.

${ }^{25}$ Tanto los cronistas medievales, como los historiadores modernos subrayan que murió joven y que se trató de una muerte repentina e inesperada. Gallus Anonimus subraya que Miecislao murió poco tiempo después de la muerte de su padre, Boleslao (Kronika Polska Anonima... op.cit., p. 47.). Jan Długosz subraya que nadie esperaba la muerte del rey puesto que este ni estaba enfermo ni era anciano (Joannis Dlugossii Annales... op.cit., p. 386 - 387.). Stanisław Kętrzyński, fundamentando sus estudios en el relato de Godofredo de Viterbo, sugirió que Miecislao II fue muerto a manos de su escudero (JASIŃSKI, Kazimierz - Rodowód... op.cit., p. 118, nota 22) Sin embargo, de acuerdo con Kazimierz Jasiński (Ibidem) y Aleksander Gieysztor (Mieszko II Lambert... op.cit., p. 34) esta versión es de poca fiabilidad.

${ }^{26}$ Compare: JASIŃSKI, Kazmierz - Rodowód... op.cit., pp. 113-120. - donde el autor expone diferentes teorías sobre este asunto.

${ }^{27}$ Kronika Thietmara... op. cit., Libro IV, p. 159.

${ }^{28}$ Ibidem, pp. 165, 166. 
tía de Richeza - hermana del emperador Otón II recibió del emperador el título de matricia, desempeñando, cuando él se ausentaba, el poder real. ${ }^{29}$

También Matilde - madre de Richeza - era, sin duda, una mujer notable. La princesa, junto con su marido Ezzo, había fundado la abadía de Brauweiler. Aunque, la decisón estuvo probablemente motivada no sólo por la caridad cristiana y gran religiosidad de sus fundadores, sino también por razones más pragmáticas el matrimonio le donó varias de sus riquezas y tierras. ${ }^{30}$ Hay que destacar que todas las hermanas de Richeza se hicieron monjas, alcanzando altos rangos conventuales. La política fundacional de la futura reina, por lo tanto, se inscribía en la tradición familiar. Las iglesias y conventos, en ese tiempo, eran centros culturales y creativos y la acción fundacional de Richeza debe ser interpretada en ese contexto. ${ }^{31}$

Al casarse con un príncipe polaco, Richeza se vio obligada a vivir en un país por muchos visto como todavía bárbaro. Polonia, recién-unida a la familia cristiana, no alcanzaba el nivel cultural de los países occidentales. Aunque su cultura material era de alto valor, las diferencias culturales eran grandes. El casamiento de Richeza y Miecislao definitivamente selló la entrada de Polonia en el mundo occidental y fortaleció vínculos entre Polonia y el Sacro Imperio Romano. Además, casando su hijo con la nieta del emperador del Sacro Imperio Romano, Boleslao pudo estrechar los lazos entre ambas naciones y con los círculos palaciegos hostiles frente al nuevo emperador - Enrique II (973 o 978 - 1024). ${ }^{32}$ Hay que destacar, que la joven dinastía de los Piastas alcanzó gracias a este matrimonio una posición igual a la de las familias importantes del Sacro Imperio. De hecho, el lazo matrimonial incrementó los contactos políticos y culturales entre Polonia y la tierra natal de la reina. Asimismo, es de suponer que gracias a este vínculo aumentó la influencia del cristianismo, puesto que Richeza empezó

\footnotetext{
${ }^{29}$ Ibidem, p. 197.

${ }^{30}$ Como destaca Michał Tomaszek, las grandes casas aritocráticas reproducían los modelos propios de la familia real. Fundar un convento o una iglesia servía, por lo tanto, como refuerzo de la posición de dicha familia y, posteriormente, como necrópolis y lugar de memoria. Puesto que Matilde descendía directamente de la casa imperial la decisión fundacional parece más que justificada. TOMASZEK, Michał - Klasztor i jego... op.cit., pp. 14-15.

${ }^{31}$ Para saber más a propósito de las mujeres de la familia de Richeza e de las mujeres de la dinastía de los Piastas veáse: ŻYLIŃSKA, Jadwiga - Piastówny i żony Piastów. Warszawa: PIW, 1967.

${ }^{32}$ La repentina muerte de Otón III provocó una serie de conflictos entre Polonia y Alemania. Hay quien afirma que el sucesor envenenó al emperador.
} 
a transformar la cultura de su patria adoptiva de acuerdo con los modelos culturales alemanes. $^{33}$

Después del casamiento, el matrimonio empezó su actividad de mecenazgo, desempeñada a través de las fundaciones. Se supone que Boleslao ofreció a los novios los terrenos de Małopolska ("Pequeña Polonia"), junto con Cracovia - su capital. De acuerdo con nuevas investigaciones, varias contrucciones sacrales del conjunto palaciego de Wawel (Cracovia) datan de los tiempos de Richeza y Miecislao, a saber, la construcción de la rotonda de Santo Felix y Adaucto y la Iglesia del Santo Gereón. Se enumeran también otras contrucciones sacrales que probablemente fueron fundadas y financiadas, o por Richeza y Miecislao, o por su hijo Casimiro. Algunos piensan que la capilla del San Martín en Breslau, es obra de Richeza y Miecislao. De acuerdo con Stanisław Trawkowski tanto el lado arquitectónico de esas construcciones sacrales, como la devoción a Santos Felix, Adaucto y Gereón, sugieren una inspiración en los círculos próximos a Richeza, cuya familia conservaba buenas relaciones con el obispo de Colonia - Pilgrim - que promovía el culto a esos santos. Hay que destacar, también, que la família de Richeza, a saber, sus padres Ezzo y Matilde, desempeñó la función del mecenazgo en el monasterio del Santo Gereón en Colonia que era en esos tiempos centro del culto de ese santo. ${ }^{34}$ Por lo tanto, esas fundaciones prueban el fuerte estímulo e influencia de la reina en las actividades fundacionales de Miecislao. ${ }^{35}$

Se supone también que Richeza, cuya familia tenía una larga tradición monástica, invitó a los benedictinos a Polonia. Por otro lado, hay que tener presente que los documentos que confirman la presencia de esta orden en Cracovia y Tyniec datan de una época posterior, i.e., del reinado de Casimiro I el Restaurador - hijo de Miecislao y Richeza. No obstante, independientemente de la época en la que llegaran monjes benedictinos a Polonia, su llegada está probablemente vinculada al mecenazgo de Richeza. ${ }^{36}$ Es de suponer, también, que Richeza mantenía contacto con sus seis hermanas que, entretanto,

\footnotetext{
${ }^{33}$ El llamado bautismo de Polonia se celebró en 966. Sin embargo, la lucha para la instalación de la nueva religión y la erradicación de los antiguos dioses duró mucho más tiempo, continuando, incluso, en vida de Miecislao.

${ }^{34}$ TRAWKOWSKI, Stanisław - "Rycheza"... op.cit., p. 369.

${ }^{35}$ SZCZUR, Stanisław - Historia Polski. Średniowiecze. Kraków: Wydawnictwo Literackie, 2002, pp. $94,100$.

${ }^{36}$ KŁOCZOWSKI, Jerzy - Dzieje chrześcijaństwa polskiego. Warszawa: Świat Książki, 2007, p. 28.
} 
llegaron a ser superiores de seis conventos importantes: Adelaide en Nivelles, Theophanu en Essen, Heylewig en Neuss, Matilde en Dütkirchen, Ida en Colonia y Sofía en Gandersheim. ${ }^{37}$ También la corte de Richeza y Miecislao fue organizada de acuerdo con los patrones occidentales. La reina hospedaba a varios hombres doctos, a hombres de la iglesia y a caballeros alemanes que formaban parte de la comitiva de la pareja de príncipes.

Después de la subida al trono, las acciones fundacionales de Miecislao y Richeza y su empeño en la difusión de la religión cristiana se vieron intensificadas en el territorio de todo el país. De acuerdo con el cronista medieval - Jan Długosz - Miecislao y Richeza el día de su boda ofrecieron a la catedral de Gniezno varias indumentarias litúrgicas y recipientes de oro y plata, empezando de esta manera su reinado. ${ }^{38}$ Les siguieron otras ofrendas y fundaciones. En los primeros años de su reinado el matrimonio fundó una nueva diócesis - el obispado en Kruszwica, posteriormente trasladado a Włocławek. Fundaron también abadía en Żmigrod. ${ }^{39}$

El reconocimiento de esas acciones vino incluso de Alemania. Matilde de Suabia envió a Miecislao sobre el año 1026, un libro litúrgico, conocido en la tradición polaca por Ordo Romanorum, acompañado de una carta en la que alababa las virtudes y el empeño fundacional del rey. ${ }^{40}$ Aunque, el claro empeño político de ese documento ${ }^{41}$ no deja lugar a dudas, la epístola confirma la erudición del rey, sus intereses y constituye un verdadero panegírico en el que se alaban las acciones culturales de la pareja real. ${ }^{42}$

Como subraya Jadwiga Żylińska, el número de las fundaciones eclesiásticas - de acuerdo con la tradición vinculados a la actuacion de Miecislao y Richeza -, de

\footnotetext{
${ }^{37}$ ŻYLIŃSKA, Jadwiga - Piastówny... op.cit., pp. 66-67.

${ }^{38}$ Joannis Dlugossii Annales... op.cit., p. 374.

${ }^{39}$ SZCZUR, Stanisław y OŻÓG, Krzysztof (coords.) - Piastowie..., op.cit., p. 44. ŻYLIŃSKA, Jadwiga Piastówny i żony Piastów. Warszawa: PIW, 1967, p. 62.

${ }^{40}$ GIEYSZTOR, Aleksander - Mieszko II Lambert... op.cit., p. 34.

${ }^{41}$ Como destacan diferentes historiadores polacos, la epístola de Matilde se inscribe en la guerra por el trono, llevada en el Sacro Imperio Romano. Matilde, aunque hermana de la mujer del emperador Conrado II, representaba la oposición. GARLICKI, Andrzej (coord.) - Poczet królów i książą Polski. Varsovia: Czytelnik, 1984, p. 38.

${ }^{42}$ GARLICKI, Andrzej (coord.) - Poczet królów... op.cit., pp. 35-38.; SZCZUR, Stanisław - Historia... op.cit., p. 77.
} 
diferentes palacios financiados por ellos ${ }^{43} \mathrm{y}$, sobre todo, de dinero y cuidado empleados en la educación de su descendencia ${ }^{44}$, demuestran que el rey y la reina no sólo conocían el valor de la cultura, sino que invertían en ella mucho dinero. ${ }^{45}$

La acción del mecenazgo, desempeñada por Richeza, no se limitó a su patria adoptiva. Cuando volvió a Alemania, dio su apoyo a la fundación de sus padres - el convento situado en Brauweiler, cerca de Colonia. Gracias al apoyo financiero de la reina, se pudo renovar gran parte de la iglesia. Además de financiar la construcción de un nuevo templo que respondía mejor a las necesidades de la comunidad conventual, la reina donó parte su herencia paterna al convento. Los monjes, a su vez, desempeñaron su papel conmemorativo, cuidando de la memoria de la familia y manteniendo fuertes lazos con los hijos de Ezzo y Matilde. ${ }^{46}$ Fueron también ellos los que escribieron Fundatio monasterii brunwilarensis, una crónica que, aunque partidista, constituye una de las principales fuentes de y sobre la familia de los Ezzonidos. ${ }^{47}$ Richeza también donó sus bienes a otros centros eclesiásticos, a saber, al obispado de Colonia y al obispado de Würzburg. Fundó también la iglesia de Santo Nicolás en Saalfeld. ${ }^{48}$ La crónica de Jan Długosz, aunque no muy favorable a la reina, confirma sus diferentes

\footnotetext{
43 Jadwiga Żylińska enumera, entre otros, los palacios en Poznań, Cracovia, Przemyśl, Lednica, si no fundados, al menos ampliados por la pareja real. En Lednica se mantuvieron huellas de una rotonda inspirada en la capilla en Aquisgrán. Se puede suponer que fue Richeza la que inspiró la construcción. ŻYLIŃSKA, Jadwiga - Piastówny... op.cit., p. 55.

${ }^{44}$ Richeza intentó transmitir sus valores a sus hijos, dándoles la mejor instrucción, de acuerdo con las corrientes intelectuales de esos tiempos. Casimiro, el hijo primogénito fue bautizado con el nombre imperial de Carlos y recibió instrucción en uno de los conventos polacos. GARLICKI, Andrzej (coord.) Poczet królów... op.cit., p. 38.; ŻYLIŃSKA, Jadwiga - Piastówny... op.cit., p. 65. También sus hijas recibieron la mejor instrucción que se podía dar a una mujer.

${ }^{45}$ ŻYLIŃSKA, Jadwiga - Piastówny... op.cit., p. 62.

46 TOMASZEK, Michał - Klasztor i jego... op.cit., p. 217.

47 Hay que reconocer que, como afirma Michał Tomaszek en su libro consagrado al monasterio brauweilense, los monjes de esa comunidad estaban disputando parte de la herencia de la reina a otro monasterio. Algunos de los hechos descritos en Fundatio monasterii brunwilarensis pudieron, por lo tanto, servir para justificar sus derechos. Hay que tener presente que, aunque Richeza ofereció gran parte de sus bienes al convento en Brauweiler, para su lugar de yacimiento designó otro monasterio que fue al que donó varias propiedades. Fundatio monasterii brunwilarensis, afirma sin embargo que Richeza fue enterrada en Colonia contra su voluntad. Esa información, como comprobó Michał Tomaszek, falsa, fue repetida por muchos historiadores polacos. La acción del mecenazgo real, no se limitó a esa comunidad particular, sino que fue ejercida en varios monasterios. Ibidem.

${ }^{48}$ TRAWKOWSKI, Stanisław - "Rycheza"... op.cit., p. 371.
} 
fundaciones. El cronista afirma que Richeza, además de entregar varios bienes a dos conventos (en Brauweiler y en Saalfeld), empleó dinero en las fundaciones. ${ }^{49}$

Aunque la reina permanecía en Alemania, su acción fundacional aparentemente continuó durante el reinado de su hijo. Se supone que fue con los fondos de Richeza con los que se reconstruyó la organización eclesiástica polaca. Fue ella quien envió a Polonia a Aaron, que en 1046 llegaría a ser obispo de Cracovia. ${ }^{50}$ Con su dinero, sus joyas y su empeño ayudó a restituir varias iglesias destruidas durante los tiempos del interregnum y del ataque de los países hostiles a Polonia. Como afirma Stanisław Szczur, Richeza y su hermano Hermann - obispo de Colonia - enviaban a Polonia no sólo riquezas y objetos litúrgicos, sino también a hombres de iglesia para que éstos apoyasen al debilitado país polaco. ${ }^{51}$ Esa interpretación moderna encuentra su confirmación en las fuentes medievales. De acuerdo con Jan Długosz, cuyas palabras punzantes estigmatizaron a la reina con tanta fuerza, Richeza ofereció a Casimiro varias joyas para que este pudiera reconstruir el reino. ${ }^{52}$

Es también en la política dinástica donde vemos la probable influencia de Richeza. Fue gracias a su auspicio, protección y autoridad, por lo que Polonia mantuvo la continuación dinástica. Fue probablemente Richeza la que ayudó a su marido en la recuperación de la herencia y del poder. Por añadidura, Richeza consiguió garantizar el mantenimiento del título real perdido por su marido. ${ }^{53}$ Su política dinástica llegó a unir la dinastía de los Piastas con otras casas reales importantes. Su hija mayor fue dada en matrimonio al futuro rey de Hungría - Bela I y, Gertrudis se casó con el prícipe ruso Iziaslav. Casimiro, a su vez, contrajo matrimonio con María Dobroniega de Kiev. Esas uniones aseguraron la posición de Polonia, intensificaron los contactos políticoculturales con otros reinos europeos y confirmaron las influencias de las dos culturas cristianas: bizantina y latina.

\footnotetext{
49 Joannis Dlugossii Annales seu Cronicae Incliti Regni Poloniae. Ed. crítica Zofia Kozłowska-Budkowa et al. Warszawa: PWN, 2009. Libro III, p. 29.

${ }^{50}$ KŁOCZOWSKI, Jerzy - Dzieje chrześcijaństwa... op.cit., p. 28.

${ }^{51}$ SZCZUR, Stanisław - Historia... op.cit., pp. 170-171.

52 Joannis Dlugossii Annales seu Cronicae... op.cit., p. 29.

${ }^{53}$ Como subraya Kazimierz Jasiński Richeza aparece con el título real tanto en documentos, como en obituarios y en su sello (Rodowód... op.cit, p. 116).
} 
Hay que destacar que todos esos matrimonios se contrajeron unos años después de la muerte de Miecislao II Lampert (entre seis y diez años), por lo tanto, aunque probablemente pactados todavía en vida de Miecislao, eran con mucha probabilidad frutos directos de la actuación de la reina. No hay que olvidar que Gertudis - hija de Richeza - es, en cierta medida, autora del primer libro litúrgico polaco. Nos referimos al Psalterium Egberti, un manuscrito del arzobispo de Tréveris traído como dote por Richeza y posteriormente ofrecido a su hija. En ese libro, en los márgenes y cartas blancas, Gertrudis escribió oraciones personales, dedicadas a su familia, sobre todo a su hijo predilecto Yaropolk Iziaslávich. Aunque igualmente hayan aparecido estudios que ponen en duda la autoría de Gertrudis, el cáracter personal de las oraciones aboga a favor de su condición de autora. ${ }^{54}$ Hay que destacar que con la familia de Richeza se vinculan también otros manuscritos, por ejemplo, Sakramentarz Tyniecki - de datación incierta -, que algunos identifican como oferta de la reina o de su hermano Hermann. ${ }^{55}$

\section{Controversias - alemana en el trono polaco y otras reinas excepcionales}

A pesar de todas estas habilidades, aparente destreza política y auspicio prestado a las instituciones religiosas, Richeza fue objeto de críticas violentas por la parte de algunos de los cronistas medievales polacos. De acuerdo con Jadwiga Żylińska - autora del libro clásico consagrado a las reinas y princesas de la dinastía de los Piastas y a las mujeres casadas con los monarcas de la primera dinastía polaca - la memoria historiográfica de la mayoría de las reinas polacas se ve distorsionada. Como destaca la estudiosa, los

\footnotetext{
54 Conocido como Salterio de Gertrudis (lat. Codex Gertrudianus) o Psalterium Egberti (aunque este segundo sea apenas una de sus partes) se divide en dos partes: la llamada Folia Gertrudiana y Salterio de Egbert. Las oraciones se encuentran tanto en las cartas blancas y márgenes del Salterio como, sobre todo en la Folia (MICHAŁOWSKA, Teresa - Ego Gertruda. Studium historycznoliterackie. Warszawa: Wydawnictwo Naukowe PWN, 2001. 9 - 10.). Todas las oraciones se encuentran escritas por la misma persona - tal vez se trate de un autógrafo de Gertrudis (Ibidem, p. 53). Aunque coincide con otros libelli precum, a saber la de Subiaco, igualmente presenta cierta originalidad. Además de loci comunes refiere acontecimientos de la vida de la misma autora (Ibidem, pp. 53-60). Las inquiriciones de historiadores siguen girando, entre otros, en torno de la originalidad de la obra y de su autoría. Conviene destacar que no todos los autores se ven de la misma opinión. A saber Henryk Łowmiański acreditaba que se trataba de una obra por encomenda. A su vez, entre otros, Zofia Kozłowska-Budkowa, Jerzy Dowiat afirmaron la autoría de Gertudis (Modlitwy księżnej Gertrudy z Psatterza Egberta z Kalendarzem. Małgorzata H. Malewicz y Brygida Kürbis (ed.). Kraków: Polska Akademia Umiejętności, 2002, pp. 43-44).

${ }^{55}$ SZCZUR, Stanisław - Historia... op.cit., pp. 103-105.
} 
cronistas tendieron a achacar las culpas o los errores de nuestros soberanos a la actuación y consejos femeninos. ${ }^{56}$

Irónicamente, las reinas más criticadas por los cronistas medievales fueron esas a las que más debe la cultura polaca. ${ }^{57}$ En nuestra opinión, los fundamentos de este fenómeno residen en las bases de la cultura del Medievo. La imagen de la mujer que guardó la cultura medieval tiene sus raízes en la cultura judío-cristiana. Se trata pues de una imagen tradicional que deriva del Génesis: somos hijas de Eva, pecadoras y entes inclinados al pecado. El Medievo, aunque en los términos de las libertades personales no limitaba a las mujeres tanto como se lo suele presentar - un ejemplo plausible de las ilustres mujeres de la dinastía de Richeza - en lo que se refiere a la imagen estableció el dominio de lo masculino. Las mujeres, a la luz de muchas crónicas, no parecían adecuadas para el papel del soberano. Eran un elemento complementario, importante, indisoluble de su marido, pero raras veces entes destinados al ejercicio del poder. En las fuentes historiográficas medievales predominaba, pues, el prototipo de la reina cristiana ideal - piadosa, caritativa, dulce, buena, fiel y pasiva, en contraste con el componente activo masculino. Las reinas que no correspondían a esa imagen por su actitud, comportamiento o claro empeño político eran criticadas, rechazadas y, sobre todo, tachadas de malas y culpables. Las mujeres que consiguieron subir hasta el poder eran representadas como incapazes de permanecer en esta esfera propiamente masculina por las debilidades de su sexo. Fue el destino historiográfico de Urraca I de León, Teresa de Portugal, Leonor de Aquitania y tantas otras reinas sobresalientes, cuyas imágenes obedecieron a estrategias y funcionalidades retóricas puestas al servicio de objetivos ideológicos o políticos.

También a las reinas consortes la cronística medieval frecuentemente guardaba el papel de "chivos expiatorios". ${ }^{58}$ Es sobre todo en las imágenes de las reinas de la Alta Edad Media en las que se vislumbra este rol de víctimas expiatorias. La escasez de fuentes escritas provenientes de la Alta Edad Media permitió ciertas ampliaciones por parte de los cronistas posteriores y abrió camino a las distorsiones. Fue a ellas a las que se

\footnotetext{
56 ŻYLIŃSKA, Jadwiga - Piastówny... op.cit., p. 61.

57 Ibidem, p. 49.

58 BAK, János M -“Queens as Scapegoats In Medieval Hungary”. In DUGGAN, Anne J. (coord.) Queens and Queenship in Medieval Europe. London: Boydell and Brewer, 1997, p. 223.
} 
echaban las culpas de los malos tiempos y los malos gobiernos. ${ }^{59}$ La reina, siendo casi por definición extranjera, era adecuada para que se acumulasen en ella odios y culpas de toda la nación. ${ }^{60}$

Además, fue en las reinas en las que se acumulaban los defectos, verdaderos o no, de sus maridos. ${ }^{61}$ La cronística medieval era, pues, algo más que una simple imagen de la realidad o reproducción de los acontecimientos. Escribir historia implicaba (e implica) diferentes procesos ideológicos, políticos, retóricos y éticos que definían la postura del cronista frente al mundo. Las crónicas del Medievo, siendo obras literarias por excelencia, recurrían a menudo a estas herramientas. De esta manera, al que parece, se estableció la imagen dual de la reina medieval: la reina cristiana ideal - humilde, delicada, piadosa - y la reina transgresora - mujer mala, desprovista de cualidades inherentes al poder, a veces, incluso, voluptuosa. Cabe destacar, que esta imagen desdoblada permanecía en perfecta concordancia con el imaginario medieval sobre las mujeres - el de cuerpo femenino exaltado y del cuerpo femenino culpable, el de Eva y María. ${ }^{62}$ El caso de Richeza parece en este sentido paradigmático: alemana, poderosa, reina durante los tiempos críticos. Textos de grandes cronistas medievales polacos también se inscriben perfectamente en estos patrones. ${ }^{63}$

Tal y como en caso de otras mujeres poderosas "la leyenda negra" de Richeza tiene sus raíces todavía en la tradición medieval. Desde la primera crónica - la llamada crónica del Gallus Anonimus (? - dsp. de 1116) - se reprocha a Richeza su antipatía hacia los polacos y la opinión negativa que tenía de ese país supuestamente ingrato y todavía pagano, ${ }^{64}$ aunque cabe destacar que la imagen totalitaria de la reina es bastante neutra.

\footnotetext{
${ }^{59}$ Ibidem.

${ }^{60}$ Ibidem, p. 228.

${ }^{61}$ Ibidem, p. 232.

${ }^{62}$ Véase por ejemplo: REGNIER-BOHLER, Danielle - "Femme/Faute/Fantasme". In FONQUERNE, Yves-René y ESTEBAN, Alfonso (coords.) - La Condición de la Mujer en la Edad Media: actas del coloquio celebrado en la Casa de Velázquez, del 5 al 7 de noviembre de 1984. Madrid: Editorial de la Universidad Complutense, 1986, pp. 475-499.

${ }^{63}$ Małgorzata Delimata también subraya la existencia de dos modelos de reinas consortes en las crónicas medievales polacas. DELIMATA, Małgorzata - "Żona Popiela oraz Rycheza i Agnieszka jako przykłady złych małżonek władców. Uwagi w świetle polskich kronik (do początku XVI stulecia)". In SIKORSKI, Dariusz A. y WRYWA, Janusz A. (coords.) - Cognitioni Gestorum: studia z dziejów średniowiecza dedykowane Profesorowi Jerzemu Strzelczykowi. Poznań - Warszawa: Wydawnictwo DiG, 2006, p. 251.

${ }^{64}$ Kronika Polska Anonima... op.cit., p. 47.
} 
A su vez el segundo gran cronista polaco - Wincenty Kadłubek (1160? - 1223) afirma que Richeza durante su supuesta regencia enaltecía a los alemanes y les concedía varios privilegios por no soportar a los representantes de altos linajes polacos. El cronista también subraya su carácter violento. Wincenty Kadłubek cita, incluso, una leyenda («aliis aliter visum est»-dice) que presupone que Richeza no era madre, sino madrastra de Casimiro el Restaurador y como tal le trató. ${ }^{65}$ Dicho sea de paso que la historia citada por Wincenty Kadłubek incluye todo el tipo de lugares comunes frecuentes en ese tipo de historias legendarias. Coincide también con los esquemas heróicos relativos a la aquisición del poder. ${ }^{66}$

De los autores medievales, el que peor (y la menos coherente) imagen transmite de Richeza es, sin embargo, Jan Długosz (1415 - 1480) y, desgraciadamente, fue su versión historiográfica la que mayor impacto tuvo en la creación de la imagen de la reina. El primer y más grave reproche del cronista son las manipulaciones a las que Richeza sometía a su marido. Afirma Jan Długosz, que Miecislao actuaba de acuerdo con los consejos de su mujer que nada tenían de certeros y causaron la miseria de su gente y de su país. ${ }^{67}$ Se le reprocha a la reina, también la imposición de impuestos y tributos que provocaron descontento del pueblo. ${ }^{68}$ Además, de acuerdo con el cronista, como regente, Richeza daba preferencia a los caballeros alemanes, ofreciéndoles altos puestos. El cronista le reprocha a la reina que no escuchara a sus consejeros y que tomara las decisiones políticas a solas. ${ }^{69}$ Se suman a esas culpas - resultantes de la debilidad femenina - codicia, sed de poder y supuesto robo de oro, plata, varias joyas, alhajas, coronas y otras insignias reales, ${ }^{70}$ que después de su destierro Richeza llevó al Emperador del Sacro Imperio Romano como símbolo de la sumisión de Polonia. ${ }^{71}$ Por otro lado, el cronista, como ya hemos subrayado, menciona las actividades fundacionales de la reina y el apoyo que dio a su hijo. Es significativo que Jan Długosz

\footnotetext{
${ }^{65}$ Kronika Polska Mistrza Wincentego tzw. Kadłubka. Trad., introd. y notas Brygida Kürbis. Wrocław: Ossolineum,1992. Libro II, capítulo 14, pp. 61-63.

66 BANASZKIEWICZ, Jacek - Polskie dzieje bajeczne Mistrza Wincentego Kadlubka. Warszawa: Leopoldinum, 1998, p. 171.

${ }^{67}$ Joannis Dlugossii Annales... op.cit., p. 385.

${ }^{68}$ Ibidem, p. 388.

${ }^{69}$ Ibidem, p. 391.

${ }^{70}$ Para saber más veáse LABUDA, Gerard - “Uwiezienie polskich insygniów...” op.cit. pp. 217-229.

${ }^{71}$ Ibidem, p. 391-392.
} 
en tanto que no aceptó a Richeza al poder, no diminuyó sus esfuerzos y acciones culturales.

Además, hay que destacar que el cronista recrimina al marido de Richeza por ese ser flaco, débil, obstinado, mezquino, perezoso, manipulado por mujeres y disoluto lo que les disgustaba a sus súbditos y a Dios. Por fuerza, el rey que no sabe garantizar armonía y bienestar a su pueblo se ve recriminado y "penalizado" por Dios. En este sentido Richeza - mala reina surge como elemento complementar de Miecislao - rey malo. De acuerdo con lo dicho por Małgorzata Delimata ${ }^{72}$ es porque en los Annales de Jan Długosz todos los malos soberanos se ven acompañados de igualmente malas esposas a las que se achaca parte de las culpas de sus maridos. ${ }^{73}$ Las imágenes de Miecislao y Richeza sirven pues de advertencia ${ }^{74}$ (Jan Długosz en la carta introductoria a su obra dice que su obra es ejemplar) y de justificación para las desgracias que sufrió posteriormente Polonia (Dios no bendecía al rey - dice el cronista).

Por otro lado, conviene destacar que la imagen de Richeza en los Annales, como ya ha subrayado Katarzyna Szafer, es por lo menos doble. ${ }^{75}$ En la primera descripción de la reina se mencionan su instrucción, buenas costumbres, belleza y alta linaje. ${ }^{76}$ Además se subraya que será buena, modesta y tierna esposa. Sin embargo, esta calificación positiva refiere-se a Richeza-novia. Richeza-esposa, Richeza-reina y, sobre todo, Richezaregente resulta ser harto diferente. También, una vez exilada en Alemania - desprovida del poder - es, en cierta manera, disculpada. Es cuando surge su actividad del mecenazgo y se describe su faceta de buena madre. También, sorprendentemente, se incrimina a los señores polacos por haber desterrado a la reina - buena o mala era al final representante del poder. ${ }^{77}$ En pocas palabras se recriminan su faceta de soberana y de mujer del rey "incapacitado". Paradójicamente su imagen incoherente puede

${ }^{72}$ Durante la primera redacción del texto no tuvimos acceso ni al artículo de Małgorzata Delimata ni al artículo de Katarzyna Szafer. Sin embargo, llegamos a las conclusiones muy parecidas a las de las autoras de los textos en causa lo que nos confirma en nuestra interpretación de la fuentes.

${ }^{73}$ DELIMATA, Małgorzata - “Żona Popiela oraz Rycheza i Agnieszka...”, op.cit., p. 252.

${ }^{74}$ Ibidem.

75 SZAFER, Katarzyna - "Wizerunek dobrej i złej władczyni w Rocznikach Jana Długosza". In Gąsiorowski Antoni (coord.) - Kobieta w kulturze średniowiecznej Europy. Prace ofiarowane Profesor Alicji Karłowskiej-Kamzowej. Poznań: PTPN, 1995, p. 91.

${ }^{76}$ Joannis Dlugossii Annales... op.cit., p. 367.

${ }^{77}$ Joannis Dlugossii Annales seu Cronicae... op.cit., p. 29. 
también resultar del rigor histórico del cronista - confrontado con varias fuentes optó por crear una imagen carente de conexión, remetente, sin embargo, a todas las tradiciones por él encontradas. ${ }^{78}$

Sea manipulación, pura retórica o tradición, las obras historiográficas posteriores repiten lo dicho por Jan Długosz, ampliando los supuestos comportamientos lamentables de la reina. Algunos incluso llegan a nombrarla depredadora (Opaliński) o fuente de maldades e instigadora (Kniaźnin). ${ }^{79}$ Richeza, que probablemente con tanto empeño e insistencia ayudó a restituir la independencia de su patria adoptiva, se transformó en los relatos posteriores en el símbolo de todos los males que sufrió Polonia por ser gobernada por extranjeros. ${ }^{80}$

Richeza, pues, de acuerdo con lo dicho por János M. Bak (a propósito de las reinas húngaras), es un "chivo expiatorio" de nuestra historia. Su imagen historiográfica medieval no sólo corresponde a la imagen de la mujer en la cultura "oficial" y en la tradición, sino que pesan sobre ella las supuestas culpas de su marido, es en ella en la que se acumula la hostilidad de los cronistas frente a la postura del rey y - tal vez frente a alemanes, es en ella en la que se pone parcialmente la responsabilidad por la debilidad del reino de Polonia. Ese elemento xenófobo y la falta de aceptación por las mujeres que consiguieron izarse hasta el poder es muy característico en la historiografía polaca. Muchas de ellas, sobre todo extranjeras (y alemanas), fueron retratadas como turbadoras, malas, demasiado ambiciosas o, incluso, demoniacas lo que nos lleva a suponer que se trata de una imposición de ciertos patrones retórico-ideológicos.

Además, en el caso específico de Richeza, se ve claramente que, confrontados con la falta de fuentes primarias, los cronistas apoyaron sus escritos en la tradición oral y repertorio legendario-mítico. Muchas de las narrativas históricas, tal y como las crónicas de Wincenty Kadłubek y de Jan Długosz, mezclan leyendas, cuentos y estereótipos con hechos históricos, confunden los nombres de diferentes personajes u omiten elementos importantes. Además escriben de acuerdo con los patrones culturales y comportamentales de sus tiempos. Los textos finales, a la fuerza, contienen

\footnotetext{
${ }^{78}$ SZAFER, Katarzyna - "Wizerunek dobrej i złej władczyni..." op. cit., p. 91.

${ }^{79}$ KOPALIŃSKI, Władysław - Stownik mitów i tradycji kultury. Warszawa: PIW, 2001, p. 1010.

${ }^{80}$ TRAWKOWSKI, Stanisław - “Rycheza”... op. cit., p. 372.
} 
omisiones y "hechos" no confirmados ni por fastos ni por investigaciones arqueológicas e históricas contemporáneas. Además, hay que tener en cuenta que las fuentes narrativas en las que se apoya la tradición, son todas posteriores al reinado de Miecislao y Richeza y como tales corresponden a un esquema de poder diferente o, incluso, se escriben al servicio de otras dinastías. En resumen, no son imparciales y están subyugadas a diferentes objetivos extra-históricos.

Es de suponer que las crónicas al reproducir esquemas, ideologías y posturas del medio de su producción constituían uno de los elementos clave de la política corriente. Richeza por ser mujer excepcional, hábil, inteligente y, sobre todo, bien formada, debía causar polémicas incluso en los tiempos de su reinado. Su origen, también debía causar polémica. Tanto en vida de Miecislao y Richeza, como posteriormente - en los tiempos de los cronistas que describieron sus vidas - las relaciones entre Polonia y los países vecinos eran bastantes tensas.

Hay que tener presente que la situación de la mujer en la Polonia medieval no se podía comparar con la de la mujer en el Sacro Imperio Romano. Todavía no existían comunidades monásticas femeninas que en otros países servían de "válvula de escape" para la creatividad femenina. Además, las leyes no daban mucha libertad a las mujeres. Richeza por lo tanto, con su postura comprometida y activa realmente traspasó los límites impuestos a su sexo, entrando en el dominio de lo masculino. Analizando su actuación, entre otros, su empeño en las fundaciones de su marido y el apoyo financiero y moral prestado a sus hijos podemos, sin embargo, dudar de su supuesto odio hacia la cultura polaca. Podemos también disculpar y entender su hipotética predilección por los alemanes y la imposición de altos tributos; Polonia necesitaba de dinero, de buenos modelos y de apoyo extranjero. Richeza intentó, y en gran medida lo consiguió, ayudar a su patria adoptiva. No deja de espantar que su patria adoptiva le "haya redimido" a ella recientemente. 


\section{Conclusiones}

Richeza, como creemos haber demostrado en el presente estudio, fue una mujer activa en el campo cultural y religioso. Aunque tuvo un papel decisivo en la política cultural de su marido y posteriormente en la reconstrucción del reino polaco - empobrecido por el interregnum y por los conflictos armados - la imagen de ella que nos llegó del Medioevo es la de una mujer turbadora, demasiado ambiciosa y desprovista de las cualidades imprescindibles para ejercer poder político. Ha sido la historiografía moderna la que ha explicado y ha resuelto los mayores desentendimientos relacionados con la figura de Richeza y ha recuperado sus méritos fundacionales y culturales.

Tanto en la historiografía polaca, como en las fuentes provenientes de otras regiones europeas, entre otras de la Península Ibérica, abundan ejemplos de reinas medievales "demonizadas". Es de suponer que las soberanas ambiciosas, que supuestamente "desafiaron" los modelos comportamentales, fueron sometidas a diferentes manipulaciones historiográficas. Analizando diferentes fuentes historiográficas medievales - tanto polacas como provenientes de otros países - podemos contemplar la sumisión de lo femenino en la imagen doble de mujer dócil/ limitada intelectualmente/ pasiva vs. mujer transgresora/ sabedora/ activa tan próxima a los estereotipos sexuales en los que todavía hoy en día se sustenta la imagen de la mujer. Fue ese imaginario, el que definió también las representaciones de las reinas poderosas y sobresalientes que supuestamente traspasaron los límites de su sexo.

La imagen de Richeza transmitida por la historiografía medieval refuerza la exclusión de la mujer del poder y muestra las consecuencias nefastas de la inclusión de la mujer en los círculos que ese poder ejercen. Su destino historiográfico es también el de muchas otras mujeres poderosas de esa época - mujeres sobresalientes que reclamaron su lugar en la historia, participaron en el ejercicio del poder, osaron gobernar ellas mismas o simple y llanamente no se correspondían con el papel de la mujer-objeto pasiva. Sin embargo, gracias a las últimas investigaciones históricas podemos decir, con mucha seguridad, que Richeza, crecida en un ambiente ilustre, transmitió sus valores a sus hijos y a su patria adoptiva y tuvo varios méritos tanto culturales, como políticos. Fue una buena madre, buena mujer, buena cristiana y, sobre todo, una reina notable y un personaje destacado en la historia y la cultura de Polonia. 
Data recepção do artigo: 31 de Março de 2013

Data aceitação do artigo: 3 de Junho de 2013

\section{Fuentes impresas}

Joannis Dlugossii Annales seu Cronicae Incliti Regni Poloniae. Ed. crítica Jan Dąbrowski et al. Warszawa: PWN, 2009. Libro I - II. ISBN 978-83-01-16068-5.

Ed. crítica Zofia

Kozłowska-Budkowa et al. Warszawa: PWN, 2009. Libro III - IV. ISBN 978-83-0116069-2.

Kronika Polska Anonima tzw. Galla. Trad. Roman Grodecki, introd. y notas Marian Plezia. Kraków: Ossolineum, 1975.

Kronika Polska Mistrza Wincentego tzw. Kadtubka. Trad., introd. y notas Brygida Kürbis. Kraków: Ossolineum, 1996. ISBN 83-04-04320-3.

Kronika Thietmara. Trad., introd., y notas Marian Zygmunt Jedlicki. Poznań: Instytut Zachodni, 1953.

List Matyldy do Mieczystawa II. In BIELAWSKI, August (ed.) - Monumenta Poloniae Historica. Volume 1. Warszawa: PWN, 1960. 323 - 324.

Mnich Brunwilerski o założeniu klasztoru w Brunwiler. In BIELAWSKI, August (ed.) Monumenta Poloniae Historica. Volume 1. Warszawa: PWN, 1960. 335 - 357.

Modlitwy księżnej Gertrudy z Psałterza Egberta z Kalendarzem. Małgorzata H. Malewicz y Brygida Kürbis (ed.). Kraków: Polska Akademia Umiejętności, 2002. 


\section{Bibliografía/ Estudios}

BAK, János M. - “Queens as Scapegoats in Medieval Hungary”. In DUGGAN, Anne J. (coord.) - Queens and Queenship in Medieval Europe: Proceedings of a Conference Held at King's College of London. London: Boydell and Brewer, 1997. ISBN 085115 $6576.223-234$.

BANASZKIEWICZ, Jacek - Polskie dzieje bajeczne Mistrza Wincentego Kadtubka. Warszawa: Wydawnictwo Leopoldinum, 1998. ISBN 83-85229-78-X.

DELIMATA, Małgorzata - "Żona Popiela oraz Rycheza i Agnieszka jako przykłady złych małżonek władców. Uwagi w świetle polskich kronik (do początku XVI stulecia)". In SIKOROSKI, Dariusz A. y WYRWA, Janusz A. (coords.) - Cognitioni Gestorum: studia $z$ dziejów średniowiecza dedykowane Profesorowi Jerzemu Strzelczykowi. Poznań - Warszawa, Wydawnictwo DiG, 2006. ISBN 83-7181-438-0. $251-259$.

GARLICKI, Andrzej et al. - Poczet królów i książat Polski. Warszawa: Czytelnik, 1984. ISBN 83-07-01104-3.

GIEYSZTOR, Aleksander - "Mieszko II Lambert". In KIENIEWICZ, Stefan (coord.) Polski Słownik Biograficzny. Kraków: IH PAN, 1976. Vol. XXI. 33 - 35.

JASIŃSKI, Kazimierz - Rodowód pierwszych Piastów. Poznań: Wydawnictwo PTPN, 2004.

KŁOCZOWSKI, Jerzy - Dzieje chrześcijaństwa polskiego. Warszawa: Świat Książki, 2007. ISBN 978-83-247-0945-8.

KOPALIŃSKI, Władysław - Słownik mitów i tradycji kultury. Warszawa: PIW, 2001. ISBN 83-06-02646-2.

LABUDA, Gerard - "Uwiezienie polskich insygniów koronacyjnych do Niemiec w 1031 r." In Gawinowa Danuta et al. - Kultura średniowieczna i staropolska: studia ofiarowane Aleksandrowi Gieysztorowi w pięćdziesięciolecie pracy naukowej, Warszawa: PWN, 1991. 217 - 229. 
MICHAŁOWSKA, Teresa - Ego Gertruda. Studium historycznoliterackie. Warszawa: Wydawnictwo Naukowe PWN, 2001.

RADZIMIŃSKI, Andrzej - Kobieta $w$ średniowiecznej Europie. Toruń: Wydawnictwo Naukowe UMK, 2012. ISBN 978-83-231-2811-3.

REGNIER-BOHLER, Danielle - "Femme/Faute/Fantasme". In FONQUERNE, YvesRené y ESTEBAN, Alfonso (coords.) - La Condición de la Mujer en la Edad Media: actas del coloquio celebrado en la Casa de Velázquez, del 5 al 7 de noviembre de 1984, Madrid, Editorial de la Universidad Complutense, 1986. ISBN 84-7491-202-4. 475-499.

SZAFER, Katarzyna - "Wizerunek dobrej i złej władczyni w Rocznikach Jana Długosza". In Gąsiorowski Antoni (coord.) - Kobieta w kulturze średniowiecznej Europy. Prace ofiarowane Profesor Alicji Karłowskiej-Kamzowej. Poznań: PTPN, 1995. ISBN 83-7063-109-6. 89-94.

SZCZUR Stanisław - Historia Polski. Średniowiecze. Kraków: Wydawnictwo Literackie, 2002. ISBN 83-08-03272-9.

SZCZUR, Stanisław y OŻÓG, Krzysztof (coords.) - Piastowie. Leksykon biograficzny. Kraków: Wydawnictwo Literackie, 1999.

TOMASZEK, Michał - Klasztor i jego dobroczyńcy. Średniowieczna narracja o opactwie Brauweiler i rodzie królowej Rychezy. Kraków: Avalon, 2007. ISBN: 9788360448-34-2.

TRAWKOWSKI, Stanisław - "Rycheza". In KIENIEWICZ, Stefan (coord.) - Polski Słownik Biograficzny. Kraków: IH PAN, 1991 - 1992. Vol. XXXIII, pp. 368-373.

WHITE, Hayden - Poetyka pisarstwa historycznego. Kraków: Universitas, 2010. ISBN 97883-242-1269-9.

ŻYLIŃSKA, Jadwiga - Piastówny i żony Piastów. Warszawa: PIW, 1967. ISBN 83-0600687-9. 


\section{COMO CITAR ESTE ARTIGO}

\section{Referência electrónica:}

DZIAŁAK, Anna - "Richeza (c. 996-1063) - la reina consorte de Polonia - sabia o instigadora?" Medievalista [Em linha]. №14, (Julho - Dezembro 2013). [Consultado dd.mm.aaaa]. Disponível em

http://www2.fcsh.unl.pt/iem/medievalista/MEDIEVALISTA14/ działak1408.html.

ISSN 1646-740X.

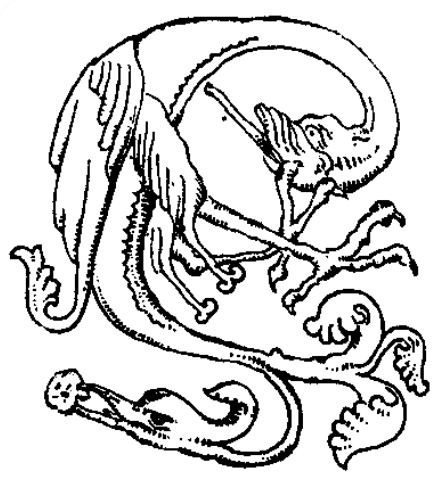

